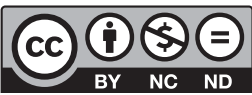

Estudos Teológicos foi licenciado com uma Licença Creative Commons Atribuição - NãoComercial - SemDerivados 3.0 Não Adaptada

http://dx.doi.org/10.22351/et.v58i2.3113

\title{
O TESTEMUNHO DA GRAÇA NO CONTEXTO DA COMEMORAÇÃo da REFORMA: PERSPECTIVAS PRÁTICAS DO DIÁLOGO CATÓLICO-LUTERANO ${ }^{1}$
}

Witnessing grace in the context of the Reformation commemoration: practical perspectives from the Catholic-Lutheran dialogue

\author{
Marcial Maçaneiro ${ }^{2}$ \\ Jefferson Zeferino ${ }^{3}$ \\ Vitor Hugo Lourenço ${ }^{4}$
}

Resumo: O presente artigo, no horizonte dos 500 anos da Reforma, pensa perspectivas práticas do ecumenismo, em especial a partir do diálogo católico-luterano, mas também a partir de outras ressonâncias eclesiais, como a tradição reformada. Desta forma, apresenta-se o documento Do Conflito à Comunhão (DCAC) em sua constituição teórica, identificandose a graça como moldura teológica do texto. A partir disso, elabora-se uma recepção católica e protestante, também como forma de contribuição e alargamento da noção de gratuidade expressa no DCAC. Com isso, a Exortação Apostólica Evangelii Gaudium (EG) e aspectos da teologia de Barth são pensados no horizonte da graça. Como resultado, percebe-se a gratuidade como ponto de partida para a construção de uma ética comum diante de uma possível nova era ecumênica.

Palavras-chave: Reforma. Diálogo ecumênico. Evangelii Gaudium. Barth. Ética.

Abstract: In the horizon of the 500 years of the Reformation, this article thinks practical perspectives of ecumenism, Catholic-Lutheran especially, but also from other ecclesial resonances like the Reformed Church. Thus, it presents the document From Conflict to Communion in its theoretical constitution identifying grace as its theological frame. From there, it elaborates a Catholic and Protestant reception of the document

1 O artigo foi recebido em 30 de agosto de 2017 e aprovado em 05 de março de 2018 com base nas avaliações dos pareceristas ad hoc.

2 Doutor em Teologia pela Pontifícia Universidade Gregoriana de Roma. Docente do Programa de Pós-Graduação em Teologia da PUCPR. Sacerdote dehoniano. Contato: marcialscj@gmail.com

3 Doutor em Teologia pela Pontifícia Universidade Católica do Paraná. Membro do Núcleo Ecumênico e de Diálogo inter-religioso da PUCPR. Membro da Igreja Evangélica de Confissão Luterana no Brasil, IECLB. Contato: jefferson.zeferino@hotmail.com

4 Mestre e doutorando em Teologia pela Pontifícia Universidade Católica do Paraná, PUCPR. Sacerdote passionista. Contato: vitorhugocp@hotmail.com 
as contribution and deepening of the idea of gratitude expressed on it. In this way, the Apostolic Exhortation Evangelii Gaudium (EG) and aspects of Barth's Works are reflected under the horizon of grace. As a result, the article comprehends gratitude as starting point for the construction of a common ethics in view of a possible new ecumenical era.

Keywords: Reformation. Ecumenical dialogue. Evangelii Gaudium. Barth. Ethics.

\section{Considerações iniciais}

Recentemente, com a atuação do papa Francisco - na esteira dos importantes passos dados pelo Concílio Vaticano II -, a unidade dos cristãos obteve renovado destaque nas instâncias centrais de governo da Igreja Católica Apostólica Romana (ICAR), com uma visibilidade que se reflete nos demais espaços ecumênicos em âmbito global.

Além disso, a aproximação do papa Francisco da igreja luterana no contexto dos 500 anos da Reforma - mediante a fundamental relação entre o Pontifício Conselho para a Unidade dos Cristãos (PCPUC) e a Federação Luterana Mundial (FLM) - sinaliza a possibilidade de um novo período na história do ecumenismo. Exemplo disso tem sido a proposta de testemunho conjunto, pela parceria entre a Caritas Internationalis e a Lutheran World Federation - World Service no cuidado a refugiados: a fé comum se traduz em ecumenismo prático de assistência àqueles que sofrem - 0 que pode motivar também uma série de outras iniciativas entre católicos e luteranos ao redor do globo.

Ademais, a comemoração dos 500 anos da Reforma também fez aumentar o interesse por Lutero, pelo contexto do século XVI e por tantos outros personagens do período que auxiliaram a construir a história do protestantismo desde então. Esse interesse foi traduzido em um grande número de publicações. ${ }^{5}$

Inspirados pela aproximação católico-luterana, esta reflexão busca apresentar elementos ecumênicos que contribuam à caminhada já iniciada e que começa a produzir seus frutos. Neste contexto, o presente trabalho reflete o quinto imperativo ecumênico formulado pela Comissão Católico-Luterana para a Unidade como referência para a práxis ecumênica. Ao compreender que "católicos e luteranos em sua pregação e serviço ao mundo devem testemunhar juntos a graça de Deus”, o documento Do conflito à comunhão ${ }^{6}$ aponta para um elemento ao mesmo tempo ético e epistemológi-

5 Destacam-se aqui alguns dossiês de revistas importantes no país que trataram da temática: 500 anos da Reforma editado por Dario Rivera, José Kaefer, Helmut Renders, Lauri Wirth e Sandra Duarte de Souza na Revista Estudos de Religião (2016); Lutero e a Reforma: 500 anos editado por Paulo Agostinho Nogueira Baptista na Revista Horizonte (2016); 500 anos da Reforma editado por Aparecida Vasconcelos e Sinivaldo Tavares na Revista Perspectiva Teológica (2017); Reforma: perspectivas da teologia bíblica e histórico-sistemática editado por Rudolf von Sinner na Estudos Teológicos (2017); Igreja e Reforma editado por Fernando Rodríguez Garrapucho, Marcial Maçaneiro e Elias Wolff na revista Pistis \& Práxis (2017).

6 PONTIFÍCIO CONSELHO PARA A PROMOÇÃO DA UNIDADE DOS CRISTÃOS; FEDERAÇÃO LUTERANA MUNDIAL. Do Conflito à Comunhão: Comemoração conjunta católico-luterana da Refor- 
co. A graça de Deus - fundamentação teológica do DCAC e da Declaração conjunta sobre a doutrina da Justificação ${ }^{7}$ - é assumida como categoria teológica dimensionadora da unidade pretendida, ao que se une a perspectiva de uma práxis de gratuidade enraizada nas formulações de ambas as tradições teológicas, ao mesmo tempo em que pode contribuir efetivamente à compreensão da vocação à unidade nas bases comunitárias católicas e luteranas.

Une-se às contribuições católicas e luteranas (representadas pelo DCAC e pela $\mathrm{EG}^{8}$ ) também o pensamento reformado (representado aqui pela teologia de Karl Barth $^{9}$ ) em virtude da recente assinatura da Declaração Conjunta sobre a Doutrina da Justificação pela Comunhão Mundial das Igrejas Reformadas.

Assim sendo, os tópicos são apresentados da seguinte forma: 1. o documento Do conflito à comunhão: uma breve apresentação com ênfase nos imperativos ecumênicos; 2. a graça na exortação Evangelii Gaudium; 3. a graça em Barth; concluindo com algumas sugestões para o testemunho da graça em perspectiva ecumênica (ao modo de considerações finais).

\section{Do conflito à comunhão: a graça e os imperativos ecumênicos}

Em seu sexto capítulo, o documento Do conflito à comunhão propõe cinco imperativos ecumênicos para as relações entre católicos e luteranos. Dizem-se imperativos porque são propostos como práxis do imperativo da unidade (cf. Jo 17.21-23) que, por sua vez, decorre do mandamento evangélico da caridade - critério para a comunhão (cf. Jo 13.34). Com efeito, católicos e luteranos abrem-se à escuta obediente da palavra de Jesus: "Nisso reconhecerão todos que sois meus discípulos: se tiverdes amor uns pelos outros" (Jo 13.35).

O capítulo sexto apresenta-se como ponto de chegada das considerações anteriores, que contextualizam a atual condição do diálogo católico-luterano (cap. I), tratando de Lutero e seu movimento (cap. II), mediante análise das repercussões e interpretações da Reforma entre luteranos e católicos (cap. III), com um exame teológico-ecumênico dos temas fundamentais da doutrina luterana (cap. IV), para que recordemos juntos a Reforma em atitude de busca da unidade e testemunho comum da Boa-Nova (cap. V). A renovada opção pela comunhão dimensiona todos esses capítulos, que incluem a confissão dos pecados contra a unidade da igreja, a afirmação

ma em 2017. Relatório da Comissão Luterana-Católico-Romana para a Unidade. Brasília: CNBB; São Leopoldo: Sinodal, 2015. n. 244. Doravante DCAC.

7 PONTIFÍCIO CONSELHO PARA A PROMOÇÃO DA UNIDADE DOS CRISTÃOS; FEDERAÇÃO LUTERANA MUNDIAL. Declaração Conjunta sobre a Doutrina da Justificação - 1999. Disponível em: <http://www.luteranos.com.br/conteudo/declaracao-conjunta-sobre-a-doutrina-da-justificacao-1999>. Acesso em: 20 maio 2014. Doravante DCDJ.

8 FRANCISCO. Exortação apostólica "Evangelii Gaudium”: sobre o anúncio do Evangelho no mundo atual. São Paulo: Paulus, 2013. Doravante EG.

9 Com efeito, esse autor não possui caráter de oficialidade para as igrejas reformadas, mas trata-se de um teólogo de envergadura no âmbito dessa tradição e alguém que recebeu o tema da graça com grande profundidade em suas formulações teóricas. 
comum do batismo que une católicos e luteranos, e a oração esperançosa para que cheguem à plena comunhão. ${ }^{10}$

É com tal abordagem que o documento chega aos cinco imperativos (cap. VI). Em sua formulação, os imperativos contemplam as disposições interiores (nível da consciência e das convicções) e exteriores (nível dos relacionamentos e práticas), que permitem a acolhida do dom da unidade entre católicos e luteranos: reconhecer e visibilizar o que há em comum; edificação recíproca pelo testemunho de uns e outros; opção pela unidade e sua busca conjunta; disposição a experimentar a força transformadora do Evangelho; testemunho conjunto da graça divina no mundo. Essas são as disposições a ser traduzidas em práxis, para que católicos e luteranos “sejam um, a fim de que o mundo creia" (Jo 17.21).

Antes, porém, de considerar cada um dos imperativos, importa notar a moldura da graça que os envolve do princípio ao fim: desde as primeiras linhas, o documento anuncia a Boa-Nova da misericórdia de Deus e a centralidade de Jesus Cristo, convocando católicos e luteranos à purificação, cura da memória e restauração da unidade, segundo o Evangelho. ${ }^{11}$ A teologia da graça favorece ainda o discernimento teológico, não só histórico, da Reforma em seus elementos pneumatológicos, uma vez que essa trataria da participação dos crentes na justiça de Cristo, no dom da regeneração e renovação, na obediência ao Evangelho que liberta, no perdão que ativa o amor para com o próximo - sempre pela força do Espírito Santo, que supera qualquer mérito humano, agindo na Palavra e nos sacramentos. ${ }^{12}$ Católicos e luteranos reconhecem sua "incessante necessidade de penitência e reforma, encorajados e conduzidos pelo Espírito Santo"13. Sob tais perspectivas é possível tratar, então, dos cinco imperativos: ${ }^{14}$

- Primeiro imperativo ${ }^{15}$ :

Mesmo que as diferenças sejam mais facilmente visíveis e experienciadas, a fim de reforçar o que existe de comum, católicos e luteranos devem sempre partir da perspectiva da unidade e não da perspectiva da divisão.

$\mathrm{Na}$ base desse imperativo está uma verdade por vezes esquecida: além de partilharem mais elementos de unidade do que de divisão, é oportuno salientar que católicos e luteranos professam em uníssono o Credo Apostólico, além do consenso nos elementos salvíficos fundamentais da fé cristã (Trindade, eficácia redentora da obra de Cristo, primado da graça, centralidade da Palavra de Deus, mediação salvífica dos sacramentos, virtudes teologais). Não é honesto partir do que ainda divide, quando se conhecem as bases de unidade. Nos relacionamentos e nos discursos, na educação e nas práticas da comunidade, católicos e luteranos podem, portanto, "sempre partir da perspectiva da

${ }^{10}$ DCAC 219-237.

${ }^{11}$ DCAC prefácio e n. 1.

${ }^{12}$ DCAC 113, 116, 118, 124, 129, 134

${ }^{13}$ DCAC prefácio; também 26, 27, 217, com importantes remissões à Declaração conjunta sobre a doutrina da Justificação.

${ }^{14}$ DCAC 239-245.

${ }^{15}$ Com o intuito de dar destaque às formulações dos imperativos ecumênicos, esses estão dispostos da forma como aqui os apresentamos, e reproduzimos o itálico utilizado originalmente no DCAC. 
unidade e não da perspectiva da divisão" (diz o primeiro imperativo). Isso implica dois cuidados: superar a unilateralidade em todas as abordagens entre católicos e luteranos; receptividade à experiência, encorajamento e crítica uns dos outros. ${ }^{16}$

Segundo imperativo:

Luteranos e católicos precisam deixar-se transformar continuamente pelo encontro com o outro e pelo testemunho mútuo da fé.

De fato, a busca pela unidade não parte da estaca zero, mas da graça da comunhão no Corpo de Cristo na força do Espírito. ${ }^{17}$ Isso tem sido experimentado por muitos católicos e luteranos em muitas comunidades do mundo, onde convivem em família, solidarizam-se nas obras de misericórdia, partilhando não só o afeto, mas também a hospitalidade e os recursos materiais. $\mathrm{O}$ chamado específico desse imperativo, no contexto dos 500 anos da Reforma, é incrementar o encontro e o testemunho já experimentados (em muitos casos) ou esquecidos e descurados (em outros casos). Exorta-se à gratidão, paciência, perseverança, zelo, amor, fé, esperança e oração como virtudes do encontro ${ }^{18}$ : virtudes que, de um lado, reforçam o encontro e o tornam habitual; de outro lado, transformam os fiéis de modo a superarem a condição restrita de pessoas e comunidades autorreferidas, para viver como pessoas e comunidades em reciprocidade. Na medida em que a convivência faz-se testemunho, possibilita-se um avanço ecumênico visível.

- Terceiro imperativo:

Católicos e luteranos devem comprometer-se outra vez na busca da unidade visivel, para compreenderem juntos o que isso significa em termos concretos, e buscar sempre de novo esse objetivo.

Apesar dos avanços em termos de encontro, reconciliação e consenso doutrinal provados nos últimos cinquenta anos, há sujeitos e comunidades sem essa memória que tendem a estagnar-se ou até regredir a estágios já superados pelo diálogo católico-luterano. Daí o imperativo de renovar o compromisso de promover a unidade visível (na caridade, no culto e no testemunho), cuidando em não voltar às oposições confessionais entre Palavra e Tradição, Evangelho e Igreja. ${ }^{19}$ Isso empenha, especialmente, a comunicação em nossas comunidades: programa formativo, escolas dominicais, catequese de jovens e adultos e presença nas mídias, além da pregação habitual. ${ }^{20}$

- Quarto imperativo:

Luteranos e católicos busquem juntos redescobrir a força do Evangelho de Jesus Cristo para o nosso tempo.

\footnotetext{
${ }^{16}$ DCAC 240.

17 DCAC 241.

${ }^{18}$ DCAC 241.

${ }^{19}$ DCAC cap. IV.

${ }^{20}$ DCAC 242.
} 
Esse imperativo aponta para a missão e o serviço, que resultam da "força do Evangelho para o nosso tempo". Fica claro que o diálogo ecumênico não se reduz à relação entre as igrejas, mas as orienta à missão conjunta, como Jesus disse: “[...] para que o mundo creia" (Jo 17.21). Traduzir esse imperativo em prática, porém, "requer mudança de mentalidade e metanoia (conversão)" ${ }^{\prime 21}$.

- Quinto imperativo:

Católicos e luteranos em sua pregação e serviço ao mundo devem testemunhar juntos a graça de Deus.

Enfim, a graça já presente nas considerações anteriores do documento (caps. I-V) volta aqui como desfecho dos cinco imperativos, completando aquela moldura teológica que mencionamos acima. Nos termos "pregação e serviço ao mundo" se incluem e reafirmam, de certa maneira, os quatro imperativos anteriores, condensados como testemunho conjunto da graça de Deus. Tomados em binômio, pregação e serviço expressam as muitas formas de luteranos e católicos praticarem o querigma e a diaconia. Isso se nota nas entrelinhas do documento, com sua ênfase na misericórdia e na justificação ${ }^{22}$, aproximando Lutero de Agostinho. A profissão conjunta de Jesus Cristo como o mediador pelo qual o Pai agracia os crentes com o Espírito de filhos (expressão da fé) leva a "testemunhar juntos a graça de Deus" nas práticas de "pregação [anúncio] e serviço [diaconia]” (expressão do amor).

Assim, a partir da lógica interna de uma teologia eclesial, afirma-se o caráter eficaz da graça, nunca redutível a um conceito doutrinal ou a uma retórica da salvação. Da parte de Deus, a graça se faz promessa cumprida, aliança para judeus e gentios, libertação do mal, justificação e filiação de alcance universal. Também da parte dos crentes - ainda que destituídos de qualquer mérito suficiente - a graça poderá ser compreendida com toda a sua eficácia, ao conformar os fiéis a Cristo pelo evangelho da misericórdia: acolhida dos peregrinos, socorro dos aflitos, defesa dos injustiçados, promoção das crianças e jovens, resgate dos exilados, enfim, promoção integral da pessoa e das sociedades (cf. Lc 10.25-37; Mt 25.35-40). Em suma, a unidade tão buscada entre católicos e luteranos tem na graça seu início e seu fim, como dádiva do Espírito à igreja $\left(=1^{\circ}, 2^{\circ} \mathrm{e}\right.$ $3^{\circ}$ imperativos) e missão conjunta em testemunho do evangelho $\left(=4^{\circ}\right.$ e $5^{\circ}$ imperativos $)$. Pode-se dizer que o que se poderia escrever sobre isso está bem exposto na Declaração conjunta sobre a doutrina da Justificação e no roteiro traçado pelo documento Do conflito à comunhão. O que falta é corresponder ecumenicamente ao caráter eficaz da graça, com uma práxis de encontro, transformação, serviço e testemunho, em todos os âmbitos das comunidades católica e luterana, conjuntamente.

${ }^{21}$ DCAC 243.

${ }^{22}$ DCAC 244-245. 


\section{A graça na exortação apostólica Evangelii Gaudium (EG)}

O quanto foi dito acima sobre a graça e sobre os cinco imperativos segue em processo de recepção nos diversos âmbitos das comunidades católicas e luteranas. Tendo isso em mente, o presente estudo dá um passo adiante: examina as formulações da exortação apostólica Evangelii Gaudium que possam ampliar e/ou projetar a compreensão da dimensão teológica acima referida, bem como sua tradução no âmbito prático.

$\mathrm{Na}$ busca de compreender as transformações sociais e os desafios do tempo presente, especialmente no que toca à evangelização, ocorreu em outubro de 2012 a XIII Assembleia Geral Ordinária do Sínodo dos Bispos, sobre o tema A nova evangelização para a transmissão da fé cristã. Com a posterior renúncia de Bento XVI, coube a Francisco o encargo de recolher em documento pontifício os anseios do episcopado e suas igrejas locais, devolvendo-os à comunidade católica de modo propositivo, com a Exortação Apostólica “A alegria do evangelho" (Evangelii Gaudium).

Por outro lado, ainda que tenha como base a reflexão sinodal, a Exortação Evangelii Gaudium (2013) ultrapassa os limites de um relatório (rapporto), indo muito além da mera síntese ou sistematização do pensamento dos bispos reunidos em assembleia. Como um "escrito autônomo"23, criativo e inovador, a primeira exortação apostólica de Francisco passa a ser uma expressão viva e programática do seu pontificado, deixando nítido seu desejo de uma transformação missionária da Igreja ${ }^{24}$.

Com a escolha de Francisco, a Igreja Católica teve a oportunidade de retomar de forma mais efetiva o caminho de abertura, diálogo e reforma propostos ao longo do Concílio, que nas três décadas seguintes foram suplantados, em muitos aspectos, por um gradativo processo de "involução eclesial" 25 . Referir-se hoje a Francisco passou a significar muito mais que um nome na longa lista dos bispos de Roma: representou (e o representa a cada dia) um novo processo na igreja, em que a eclesiologia de comunhão delineada pelo Vaticano II vem dinamizada com ações de uma efetiva "reforma da Igreja em saída missionária" ${ }^{26}$. Essa reforma acolhe o diálogo como via da evangelização ${ }^{27}$, destacando a promoção ecumênica da unidade dos cristãos. ${ }^{28}$

Vindo de um continente marcado pela diversidade cultural e pelo pluralismo religioso, Francisco, depositário da tradição latino-americana, recorda em sua exortação que o ecumenismo e a unidade são expressões do desejo de Cristo assim como elaborado pela tradição joanina: "Que todos sejam um, para que o mundo creia" (Jo

\footnotetext{
${ }^{23}$ SUESS, P. Dicionário da Evangelii Gaudium: 50 palavras-chave para uma leitura pastoral. São Paulo: Paulinas, 2015. p. 8.

24 EG 14, 27.

25 BRIGHENTI, A. Perfil pastoral da Igreja que o papa Francisco sonha. In: SILVA, José Maria (Org.). Papa Francisco: perspectivas e expectativas de um papado. Petrópolis: Vozes, 2014. p. 13.

${ }^{26}$ EG 17.

27 EG 238.

28 EG 244-246.
} 
17.21). Retomando algumas proposições conciliares ${ }^{29}$, o papa enfatiza que a credibilidade do anúncio evangélico seria muito maior se os cristãos superassem as divisões e os conflitos, vivendo em plenitude a "catolicidade" própria de sua condição de "filhos, pelo Batismo"; e conclui: "devemos sempre lembrar-nos de que somos peregrinos, e peregrinamos juntos. Para isso, devemos abrir o coração ao companheiro de estrada, sem medos nem desconfianças, e olhar primariamente para o que procuramos: a paz no rosto do único Deus"30.

Diante dos novos desafios que se descortinam no campo social, político e religioso, a divisão entre os cristãos torna-se ainda mais grave, configurando-se como contratestemunho de todos os batizados frente à sociedade que cobra, cada vez mais, a autenticidade dos crentes. Nessa perspectiva, Francisco considera urgente o empenho comum por caminhos de unidade. Pela extensão do testemunho e do serviço, o ecumenismo supera o quadro das confissões cristãs, tornando-se uma verdadeira "contribuição para a unidade da família humana"31.

Pensando na contribuição que os cristãos podem oferecer ao mundo, a partir de uma consciência ecumênica e práticas comuns, Francisco exorta os que se propõem a andar pelas sendas da unidade a serem "fermentos de paz". Partindo do pressuposto de que aquilo que une os cristãos é mais forte do que aquilo que os separa, afirma que no ecumenismo não se trata "apenas de receber informações sobre os outros para os conhecermos melhor, mas de recolher o que o Espírito semeou neles como um dom também para nós" ${ }^{\prime 2}$.

Por meio de gestos e atitudes concretas, o Bispo de Roma tem recuperado e ressignificado o sentido básico do ministério de Pedro: testemunhar a Cristo e confirmar a fé dos irmãos (cf. Mt 16.16; Lc 22.32). Agindo como pontifex (construtor de pontes), Francisco tem se aproximado e revelado seu apreço pelas demais confissões religiosas, como o judaísmo e o islã, além de sua atenção aos não crentes, mostrando a importância do diálogo, da cooperação e da busca comum pela construção da paz, para consolidar a justiça entre os povos e o cuidado pela Criação. ${ }^{33}$

Como expressão concreta de seu empenho ecumênico, ao se propor a participar do início das comemorações do quinto centenário da Reforma Protestante, realizada na Catedral de Lund (Suécia), Francisco reconhece a importância da Reforma na história da igreja, discernindo junto aos luteranos o quanto dela decorreu, sejam os benefícios, sejam as feridas a curar, para a plena edificação da igreja, Corpo de Cristo. Ao se dirigir à "casa dos luteranos", esse "papa ecumênico" se mostra irmão, se faz família, sente-se parte daquela porção de cristãos entre os quais surgiu, séculos atrás, a Reforma. Perdoando-se mutuamente conforme pede o Senhor (cf. Mt 6.12), católicos

${ }^{29}$ CONCÍLIO VATICANO II. Decreto Unitatis Redintegratio sobre o Ecumenismo. Disponível em: $<$ http:// www.vatican.va/archive/hist_councils/ii_vatican_council/documents/vat-ii_decree_19641121_unitatis-redintegratio_po.html>. Acesso em: 30 ago. 2017. n. 4.

${ }^{30}$ EG 244.

${ }^{31}$ EG 245.

32 EG 246.

${ }^{33}$ EG 257. 
e luteranos assumem o compromisso de testemunhar juntos a graça de Deus, lutando contra a divisão que historicamente causou tantos sofrimentos e incompreensões.

Na exortação apostólica Evangelii Gaudium, a graça divina encontra um espaço privilegiado de reflexão e proposição, como dádiva de um Deus presente à vida das pessoas, das confissões religiosas e do mundo. Já nas primeiras abordagens sobre o tema, Francisco relaciona a graça com a prática dos cristãos na atualidade. Contemplando partes de uma igreja e sociedade marcadas pelo egoísmo, por posturas reacionárias, legalistas e farisaicas, importa reconhecer nas obras de caridade, no amor fraterno, no respeito pelo outro, a "manifestação mais perfeita da graça interior do Espírito"34. Em um mundo dilacerado por discórdias - frisa o Papa -, "não podemos falar mais da lei do que da graça"35.

Quando não há uma abertura para o diálogo ecumênico e inter-religioso, para o diferente e especialmente para os que estão à margem da sociedade, a igreja corre o risco de agir "como controladora da graça e não como facilitadora". Na perspectiva de Francisco, a "Igreja não é uma alfândega; é a casa paterna, onde há lugar para todos com a sua vida fadigosa"36. Pois o cristão é chamado a manifestar, em sua vida e relações, que "onde abundou o pecado, superabundou a graça” (Rm 5.20). A fé professada é desafiada pela esperança a "entrever o vinho em que a água pode ser transformada, e a descobrir o trigo que cresce no meio do joio" 37 .

Reconstruindo uma imagem positiva do ser humano e da facticidade de sua existência, a Evangelii Gaudium exorta a reconhecer a ação de Deus na cotidianidade do tempo e do espaço. Entende o papa que, em meio às vicissitudes e ambiguidades da condição humana, Deus manifesta sua graça, fazendo aquilo que é considerado fraco tornar-se forte, superando divisões e conflitos, como experimentou Paulo: "Basta-te a minha graça, porque a força manifesta-se na fraqueza" (2Co 12.9). Tendo ante os olhos as experiências humanas positivas e a superação dos limites e do mal que podem ferir a unidade dos cristãos, Francisco enfatiza: "O triunfo cristão é sempre uma cruz; mas cruz que é, simultaneamente, estandarte de vitória, que se empunha com ternura batalhadora contra as investidas do mal"38.

Visando à evangelização, à transformação social e ao diálogo ecumênico, esse papa latino-americano reconhece que a igreja precisa experenciar um processo de "conversão pastoral e missionária", com efetivo "significado programático" para os sujeitos e as estruturas eclesiais. ${ }^{39}$ Em sua compreensão eclesiológica, Francisco analisa que uma igreja rígida, preocupada em excesso com aspectos doutrinais e disciplinares, fechada em suas seguranças, dá vazão a posturas elitistas, narcísicas e autoritárias, não favorecendo, assim, o florescimento de uma consciência ecumênica, uma evangelização que toca dados sociais e que comunica efetivamente a graça divina. A

\footnotetext{
34 EG 37.

35 EG 38.

36 EG 47.

${ }^{37}$ EG 84.

38 EG 85.

39 EG 25.
} 
esse respeito o papa adverte: "Em vez de evangelizar, se analisam e classificam os demais e, em vez de facilitar o acesso à graça, consomem-se as energias a controlar"

Em uma sociedade marcada pelo pluralismo religioso em suas várias manifestações, cabe, de acordo com Francisco, sempre "pedir a graça de nos alegrarmos com os frutos alheios, que são de todos" ${ }^{\prime 4}$. Isso inclui reconhecer que, nas buscas pelo Transcendente, "todos fomos por pura graça atraídos por Deus". Compreende-se que, neste Deus - que toma a iniciativa de comunicar-se e de congregar a família humana - todos estariam irmanados em suas existências. Neste contexto, torna-se referência "o princípio da primazia da graça, farol que ilumina constantemente as nossas reflexões sobre a evangelização "’2 , para seguir peregrinando juntos na estrada da unidade cristã. ${ }^{43}$

Nessa forma de compreensão do sagrado, a graça divina suporia a diversidade de culturas, povos e tradições; encarnando-se, por assim dizer, na vida de quem se dispõe sinceramente a experimentá-la, na diversidade dos credos. Nas palavras de Francisco, "a graça supõe a cultura, e o dom de Deus encarna-se na cultura de quem o recebe" ". Além disso, a graça é expressa na ideia de "missionariedade", na capacidade de "sair de si" para "peregrinar juntos" ${ }^{\text {", }}$, partilhando as diferenças que enriquecem. O dom gratuito da vida, da filiação divina e da graça salvadora que abraça todos e todas, seria "a condição que torna possível constante santificação" os batizados, das diferentes confissões, no mesmo projeto de discipulado e missão segundo o Evangelho.

Em síntese, a exortação Evangelii Gaudium retoma o primado da graça seriamente, afirmando sua importância e apontando seus desdobramentos para o fortalecimento da consciência e da caminhada ecumênicas, especialmente entre católicos e luteranos, no contexto dos 500 anos da Reforma. "Justificados por meio da graça de Deus e associados ao mistério pascal de Jesus Cristo" ${ }^{47}$, católicos e luteranos são convidados a reafirmar seus laços, aquilo que os une e os faz irmãos, caminheiros de um mesmo caminho.

\section{A graça na tradição protestante: elementos teológicos para uma ética ecumênica}

Em continuidade com a Evangelii Gaudium e a ampla tradição católica, para o protestantismo o tema da graça é basilar. Assim, cabe agora atentar a elementos que possam cooperar para uma cultura de diálogo embasada na ideia de gratuidade em sua dimensão ética. Da mesma forma, cabe destacar que os imperativos ecumênicos

${ }^{40}$ EG 94.

${ }^{41}$ EG 99.

${ }^{42}$ EG 112.

${ }^{43}$ EG 244.

${ }^{44}$ EG 115.

${ }^{45}$ EG 124.

${ }^{46}$ EG 162.

${ }^{47}$ EG 254. 
propostos pelo documento Do Conflito à Comunhão são aqui compreendidos como um chamado à ação. Neste sentido, cabe alocá-los no horizonte da ética teológica.

A voz de Francisco, no mundo católico, possui notável representatividade e força de apelo. Além disso, ainda que a exortação Evangelii Gaudium não seja normativa em sentido estrito, é um documento com "sentido programático e consequências importantes"48. Distintamente, o mundo protestante não possui um sumo pontífice, além do fato de que cada tradição (reformada, luterana, metodista etc.) possui autonomia. Dentro do protestantismo, o pensamento de Karl Barth, reconhecido como um dos mais destacados teólogos protestantes do século XX, emerge como parceiro nessa reflexão também como forma de ressoar a recente associação da Comunhão Mundial das Igrejas Reformadas à Declaração Conjunta sobre a Doutrina da Justificação. ${ }^{49}$

\section{O primeiro mandamento na interpretação de Barth}

A leitura de Barth é feita a partir de sua interpretação do primeiro mandamento, pois essa é ilustrativa de sua interpretação bíblica na medida em que se destaca aí seu cristocentrismo. ${ }^{50}$

A compreensão de Barth sobre o primeiro mandamento se dá, sobretudo, a partir de duas características: 1. o autor compreende o primeiro mandamento como axioma teológico; 2. a leitura de Barth, ao modo do was Christum treibet, de Lutero, faz uma leitura do Antigo Testamento à luz do Novo Testamento. Com isso, o autor compreende que já o primeiro mandamento fala de Jesus Cristo.

Para Barth, reconhecer o primeiro mandamento como o axioma teológico significa dar "a esse conceito teor e sentido tal como ele somente pode ter na teologia". É necessário perceber que "o primeiro mandamento constitui uma instância sui generis" ${ }^{51}$. Para Barth,

Com o conceito de "axioma" ocorre o mesmo que se dá com todos os elementos da linguagem humana [...] em si não apresenta analogia àquilo que ele objetiva caracterizar em seu uso teológico. Quando muito ele poderá adquirir uma "analogia da fé"

48 EG 25.

49 “'...] a Comunhão Mundial das Igrejas Reformadas também assinou um acordo de associação à 'Declaração Conjunta Católico-Luterana sobre a Doutrina da Justificação’ de 1999. Na presença também dos outros signatários do texto, a Igreja Católica, representada pelo secretário do Pontifício Conselho para a Unidade dos Cristãos, o bispo Brian Farrell, e o Conselho Metodista Mundial, que, por sua vez, ratificou o texto em 2006, representado pelo secretário-geral, o bispo Ivan Abrahams, os reformados, assim, aderiram, trazendo as suas ênfases e atenções específicas, particularmente sobre a relação integral entre justificação e justiça". GEYMONAT, C. Igrejas reformadas assinam Testemunho de Wittenberg [07.07.2017]. Disponível em: $<$ https:/www.conic.org.br/portal/noticias/2280-igrejas-reformadas-assinam-testemunho-de-wittenberg $>$. Acesso em: 07 ago. 2017.

${ }_{50}$ Para essa parte utilizamos de forma livre e com alterações excertos de: ZEFERINO, J. A fundamentação da ética na teologia de Karl Barth: impulsos para a práxis cristã hoje. Orientador C. Boff. 2015. Dissertação (Mestrado) - Pontifícia Universidade Católica do Paraná, Curitiba, 2015.

51 BARTH, K. O primeiro mandamento como axioma teológico. In: BARTH, K. Dádiva e Louvor: ensaios teológicos de Karl Barth. 3. ed. São Leopoldo: Sinodal; EST, 2006. p. 127. 
(Romanos 12.6) dentro deste uso. Mercê desta analogia recebida [...] é que ele então de fato poderá servir de ponto de contato para um diálogo sobre a premissa teológica. [...] A teologia não está em condições de respeitar em caráter definitivo o sentido próprio da linguagem, em qualquer ponto que seja. Ela de forma alguma pode aceitá-la como superiora. Dizemos, portanto, "axioma" porque com este conceito a linguagem nos oferece uma oportunidade de tentar dizer aquilo que mesmo e justamente esse conceito em si e em seu uso generalizado não poderia dizer: o que representa a premissa teológica por excelência fundamentada e fundamentadora ${ }^{52}$.

Para Barth, é essencial que o axioma esteja escrito (Êx 20). Enquanto parte do documento que dá identidade à comunidade eclesial, que a partir da "vida da igreja é que também a teologia tem sua existência" ${ }^{53}$. Ao possuir essa base escrita, "suas sentenças em princípio só podem ser interpretação". Segundo Barth, o conteúdo expresso pelo primeiro mandamento também poderia ser reconhecido em "João 1.14: 'O Verbo se fez carne e habitou entre nós, e vimos a sua glória'; ou a palavra de Mateus 11.28: 'Vinde a mim todos os que estais cansados e sobrecarregados!'; como também poderíamos indicar a passagem em 2 Coríntios 5.19: 'Deus estava em Cristo, reconciliando consigo o mundo" "54. Para ele, "o primeiro mandamento, o axioma teológico, não é acessível de modo direto, imediato e geral, mas 'está escrito' e somente é axioma pelo fato e no fato de estar escrito". Além disso, possui validade para uma determinada comunidade, pois é "escrito para uma igreja na qual ele tem autoridade e a qual por excelência somente existe pelo fato de ela ler e proclamar isto que está escrito"

No primeiro mandamento está em pauta uma relação temporal de Deus com o ser humano. Em jogo está "uma história a se desenrolar dentro do tempo, uma história entre Deus e pessoa humana". Desta forma, "que a palavra se tornou carne, que Deus fala humanamente ao ser humano, dentro do modo humano de ser, portanto, e dentro do tempo, este já é o sentido do próprio livro do Êxodo". Disso resulta que o primeiro mandamento só se torna axioma teológico para quem o ouve. ${ }^{56}$ "Somente entende o axioma teológico quem a seu tempo precisa engolir a mesma interpelação de Deus temporalmente determinada que o israelita no Sinai teve que engolir a seu tempo, querendo ou não." 57 Para Barth, "o axioma teológico se reconhece pelo fato de somente possuir realidade e validade no momento [...] temporal de sua revelação". A palavra eterna de Deus se encarna no tempo, e é ali que ela atua. ${ }^{58}$

$\mathrm{O}$ axioma teológico deve ser entendido enquanto mandamento. "Essencialmente ele não é apenas uma informação de Deus a respeito de si mesmo." Trata-se, antes, "de um mandamento de Deus para a pessoa individualmente por ele endereçada em Israel. Deus não apenas se denomina o senhor, mas ele se comporta como tal”, de-

\footnotetext{
52 BARTH, 2006, p. 128.

53 O que é tematizado em Existência Teológica Hoje, artigo do mesmo ano que o texto da presente análise.

54 BARTH, 2006, p. 128.

55 BARTH, 2006, p. 129.

56 Aspecto que dialoga com o homo audiens de Lutero.

57 BARTH, 2006, p. 129.

${ }^{58}$ BARTH, 2006, p. 130.
} 
mandando sua exclusividade. Porque Deus se coloca diante do ser humano enquanto Senhor, "o axioma teológico é essencialmente uma tomada de posição divina". Não ouvir o mandamento de Deus significa desobediência, enquanto que o contrário implica obediência. "A verdade divina a qual [...] é dita através do mandamento, vem até ela [a pessoa humana] [...] através de uma decisão divina e [...] numa decisão humana em resposta àquela. ${ }^{\circ 9}$

Aquele que dá o primeiro mandamento se mostra como libertador e salvador, pois relembra a libertação do Egito. Este, "dentro da liberdade de sua misericórdia [...] escolheu a Israel", e assim, "estabeleceu", "cumpriu" e "comprovou" um "pacto". O Deus do primeiro mandamento é aquele que já havia confirmado sua bondade na história relacional que possui com seu povo. Na relação com ele, a obediência tem a ver com o reconhecimento e rememoramento da ação de Deus na história. "O axioma teológico não pode ser isolado desse contexto soteriológico ou, sejamos logo concretos, cristológico." Por isso a revelação implica "conciliação", de acordo com o "pacto instaurado e cumprido por Deus entre si mesmo e as pessoas humanas" ${ }^{\prime 60}$. Desta forma, o autor compreende que "Jesus Cristo é o sentido da lei do Sinai, na medida em que esta é revelação de Deus". Assim, o axioma teológico expressa "eleição divina, pacto, graça, perdão dos pecados". O axioma teológico é válido "dentro da igreja, na qual a mensagem sobre este reino é ouvida, crida e anunciada". Para ele, "um axioma que se julga poder deduzir abstratamente da criação, seja lá o que for, com certeza não é um mandamento de Deus, não é axioma teológico". O primeiro mandamento "é a palavra que Deus dirige aos seus, aos seus eleitos e vocacionados" ${ }^{1}$.

O primeiro mandamento, ao rejeitar outros deuses, implica que, e aqui Barth se baseia em Lutero, "um deus é aquilo em que a pessoa deposita sua confiança, ao qual ela dá fé, do qual ela espera que lhe dê o que ela ama e a guarde daquilo que teme". Em outras palavras, "um deus é aquilo a que a pessoa entrega o seu coração". O primeiro mandamento rejeita que se coloque qualquer coisa no lugar ou ao lado do Deus que se revela enquanto "Deus ecclesiae" (o Deus da Igreja) ${ }^{62}$.

Ao compreender o primeiro mandamento como axioma teológico, Barth percebe um critério, um lugar a partir do qual é possível pensar a fé. Para ele, é importante que o axioma esteja escrito. Porém, justamente por isso é que o axioma requer interpretação. Por outro lado, o primeiro mandamento diz respeito a experiência de se confiar em Deus. Para Barth, a decisão de Deus de tornar-se Deus do ser humano, de ser aquele que se coloca como Deus do humano também abre espaço à decisão humana em resposta à decisão de Deus. Além disso, ao compreender o primeiro mandamento como a apresentação do Deus cristão, Barth enxerga já ali um cristocentrismo, cuja base é a graça. Isto é, no primeiro mandamento o teólogo de Basileia percebe a centralidade da pessoa de Jesus Cristo, o que, em consequência, faz com que este

\footnotetext{
59 BARTH, 2006, p. 130.

${ }^{60}$ BARTH, 2006, p. 131.

${ }^{61}$ BARTH, 2006, p. 132.

62 BARTH, 2006, p. 133.
} 
mandamento tenha a ver com a comunidade cristã. Isto é, trata-se do primeiro mandamento referente ao Deus ecclesiae.

\section{Considerações sintéticas}

Com efeito, a elaboração de Barth recepciona o decálogo no horizonte da graça. Esse não tarda em interpretar o Deus do primeiro mandamento como o Pai de Jesus Cristo. Isso se reflete de modo específico na recepção cristã do decálogo, isto é, trata-se de uma apropriação de uma tradição anterior mediada por um dado característico de releitura da fé. A graça é esse dado. Barth chega ao ponto de identificar Jesus Cristo como a representação da graça de Deus. O Deus de Barth é expressão de gratuidade. Essa noção da graça como ponto de partida para a reflexão teológica motiva também a presente recepção do diálogo ecumênico católico-luterano.

\section{Considerações finais: $o$ testemunho da graça como tarefa ecumênica}

As elaborações acima expostas comunicam-se a partir de três vertentes, por assim dizer, no cenário das igrejas: o magistério católico, na esteira do Concílio Vaticano II, com papa Francisco (Evangelii Gaudium), o documento Do Conflito à Comunhão, e a teologia de Barth, como representante da tradição reformada. Pensa-se que a reflexão teológica ecumênica possui como fonte primeira o evangelho da graça e da misericórdia. Assim, destacamos as seguintes perspectivas práticas para o testemunho ecumênico da graça, no contexto dos 500 anos da Reforma:

- Curar a memória para reconciliar a igreja: avançar na via da reconciliação, no caminho já aberto pelo acordo sobre a justificação, bem como pela celebração do perdão presidida por João Paulo II em 12 de março do ano 2000 (Roma), com menção dos pecados contra a unidade do Corpo de Cristo. Declarações anteriores incluíram nessa cura da memória os casos de Lutero e Calvino, considerados pela Comissão Teológica Internacional. ${ }^{63}$ Isso nos pede revisão histórica e teológica do passado, para celebrarmos a reconciliação (cf. 1Co 5.18-20) com gestos que a expressem, educando as comunidades do presente e do futuro nessa perspectiva. Soma-se a isso a formulação de Barth que, a partir da tradição cristã, graça implica conciliação, na medida em que se pensa um movimento restaurativo em favor de.

- Tomar o documento Do Conflito à Comunhão como ponto de partida para a elaboração de mais textos teológicos comuns entre católicos, luteranos e re-

${ }^{63}$ COMMISSIONE TEOLOGICA INTERNAZIONALE [CTI]. Memoria e riconciliazione: la Chiesa le colpe del passato. Casale Monferrato: Piemme, 2000. p. 100-104; BENAZZI, N. Sussidi storici. In: COMMISSIONE TEOLOGICA INTERNAZIONALE [CTI]. Memoria e riconciliazione: la Chiesa le colpe del passato. Casale Monferrato: Piemme, 2000. p. 162-171. 
formados, que favoreçam a superação das unilateralidades e oposições confessionais que ainda houver, sugerindo ações de encontro, compreensão e colaboração mútua. A gratuidade, por sua vez, emerge como termo agregador a partir do qual as referidas formulações teológicas podem ser pensadas.

- Educar para relações ecumênicas que incidam cada vez mais nos níveis de liderança e das comunidades locais, fomentando uma nova compreensão do outro e dos elementos confessionais à luz dos documentos sobre a justificação e Do conflito à comunhão. Isso educará as posturas e as relações com uma hermenêutica da comunhão, que parte do que já nos une e acolhe as diferenças não sob a marca da oposição, mas como ênfases complementares da fé e da realização da igreja de Cristo.

- Fomentar a prática dos cinco imperativos ecumênicos a partir dos ministérios locais, em sua múltipla funcionalidade e interação, com atenção aos meios formativos (cursos, seminários, catequese, escola bíblica, faculdades teológicas) e ênfase nas novas gerações.

Efetivamente, o que se propõe é que as tradições católica e protestantes estabelecem a graça de Deus como elemento fontal. Essa graça é compreendida no horizonte da imagem de um Deus que se esvazia para fazer-se presente (kênosis) e que, tornando-se humano, humaniza as relações humanas (Jesus de Nazaré). Parte-se, portanto, da compreensão de um sentido de Deus que alarga as experiências humanas em suas potencialidades de gratuidade no horizonte de uma convivialidade ecumênica.

\section{Referências}

BAPTISTA, P. (Ed.). Lutero e a Reforma: 500 anos. Horizonte, Belo Horizonte, v. 14, n. 44, out./dez. 2016.

BARTH, K. O primeiro mandamento como axioma teológico. In: BARTH, K. Dádiva e Louvor: ensaios teológicos de Karl Barth. 3. ed. São Leopoldo: Sinodal; EST, 2006. p. 127-139.

BENAZZI, N. Sussidi storici. In: COMMISSIONE TEOLOGICA INTERNAZIONALE [CTI]. Memoria e riconciliazione: la Chiesa le colpe del passato. Casale Monferrato: Piemme, 2000. p. 131-180. BÍBLIA DE JERUSALÉM. Nova edição revista. São Paulo: Paulus, 2002.

BRIGHENTI, A. Perfil pastoral da Igreja que o papa Francisco sonha. In: SILVA, José Maria (Org.). Papa Francisco: perspectivas e expectativas de um papado. Petrópolis: Vozes, 2014.

COMMISSIONE TEOLOGICA INTERNAZIONALE [CTI]. Memoria e riconciliazione: la Chiesa le colpe del passato. Casale Monferrato: Piemme, 2000.

CONCÍLIO VATICANO II. Decreto Unitatis Redintegratio sobre o Ecumenismo. Disponível em: $<$ http://www.vatican.va/archive/hist_councils/ii_vatican_council/documents/vat-ii_decree_19641121_unitatis-redintegratio_po.html >. Acesso em: 30 ago. 2017.

FRANCISCO. Exortação apostólica "Evangelii Gaudium": sobre o anúncio do Evangelho no mundo atual. São Paulo: Paulus, 2013.

GEYMONAT, C. Igrejas reformadas assinam Testemunho de Wittenberg [07.07.2017]. Disponível em: $<$ https://www.conic.org.br/portal/noticias/2280-igrejas-reformadas-assinam-testemunho-de-wittenberg>. Acesso em: 07 ago. 2017.

PONTIFÍCIO CONSELHO PARA A PROMOÇÃO DA UNIDADE DOS CRISTÃOS; FEDERAÇÃO LUTERANA MUNDIAL. Do Conflito à Comunhão: Comemoração conjunta 
católico-luterana da Reforma em 2017. Relatório da Comissão Luterana - Católico-Romana para a Unidade. Brasília: CNBB; São Leopoldo: Sinodal, 2015.

PONTIFÍCIO CONSELHO PARAA PROMOÇÃO DA UNIDADE DOS CRISTÃOS; FEDERAÇÃO LUTERANA MUNDIAL. Declaração Conjunta sobre a Doutrina da Justificação - 1999. Disponível em: < http://www.luteranos.com.br/conteudo/declaracao-conjunta-sobre-a-doutrina-da-justificacao-1999>. Acesso em: 20 maio 2014.

RIVERA, D. et al. (Eds.). 500 anos da Reforma. Estudos de Religião, São Bernardo do Campo, v. 30, n. 2, maio/ago. 2016.

RODRÍGUEZ GARRAPUCHO, F.; MAÇANEIRO, M.; WOLFF, E. (Eds.). Igreja e Reforma. Pistis e Práxis, Curitiba, v. 9, n. 2, maio/ago. 2017. Dossiê temático.

SINNER, Rudolf von (Ed.). Reforma: perspectivas da teologia bíblica e histórico-sistemática. Estudos Teológicos, São Leopoldo, v. 57, n. 1, jan./jun. 2017.

SUESS, P. Dicionário da Evangelii Gaudium: 50 palavras-chave para uma leitura pastoral. São Paulo: Paulinas, 2015.

VASCONCELOS, A.; TAVARES, S. (Eds.). 500 anos da Reforma. Perspectiva Teológica, Belo Horizonte, v. 49, n. 1, jan./abr. 2017.

ZEFERINO, J. A fundamentação da ética na teologia de Karl Barth: impulsos para a práxis cristã hoje. Orientador C. Boff. 2015. Dissertação (Mestrado) - Pontifícia Universidade Católica do Paraná, Curitiba, 2015. 